\title{
Brine shrimp cytotoxicity of crude methanol extract and antispasmodic activity of a-amyrin acetate from Tylophora hirsuta Wall
}

Niaz Ali

\begin{abstract}
Background: We have previously reported that aerial parts of Tylophora hirsuta have antispasmodic profile. The current work is an attempt for isolation of pharmacologically active compound(s) that contribute for its antispasmodic activity.

Methods: Preliminary phytochemical screening for crude methanol extract of Tylophora hirsuta (Th.Cr) is performed. Brine shrimp cytotoxicity of crude methanol extract is performed. Column chromatography was used for isolation of compounds. Mass spectroscopy, $H^{1}$ NMR and $C^{13}$ NMR were used for structural determination of compounds. a-amyrin acetate was tried for possible spasmolytic activity in rabbit's jejunal preparations and KCl-induced contractions.
\end{abstract}

Results: Th.Cr tested positive for saponins, alkaloids, flavonoids and terpenoids. Compound 1 was isolated as a-amyrin acetate. Compound 2 was heptaeicosanol. Crude methanol extract tested positive for brine shrimp cytotoxicity with $\mathrm{LC}_{50} 492.33 \pm 8.08 \mathrm{mg} / \mathrm{ml}$. Compound 1 tested positive for antispasmodic activity on spontaneous rabbits' jejunum preparations with $\mathrm{EC}_{50}(60 \pm 2) \times 10^{-5} \mathrm{M}$. The compound also tested positive on $\mathrm{KCl}$ induced contractions with $\mathrm{EC}_{50}(72 \pm 3) \times 10^{-5} \mathrm{M}$.

Conclusions: The present work confirms that a-amyrin acetate is has antispasmodic profile and the relaxant effect may be attributed to a-amyrin acetate which is a major compound.

\section{Background}

Tylophora hirsuta belongs to family asclepiadaceae (common name: Tylophora) which is of great medicinal importance [1,2]. It is a shrub that belongs to family asclepiadaceae [1]. Asclepiadaceae is mainly distributed in the tropical and subtropical regions of the world, which have 175-180 genera and 2200 species as reported by Yasin J. Nasir (1983) [1]. Family asclepiadaceae has great ethnobotanical importance in the treatment of different diseases [3]. For example, Dregea volubilis is used in the treatment of snake bites and skin infections like boils and cellulites. Oxystelma racamone is used in the treatment of sore throat and jaundice. While Pentatropis spiralis is emetic and astringent. It is also used in the treatment of gonorrhoea. Ceropegia bulbosa is used in the treatment of digestive disorders, and tonic as well. Similarly, Pergularia daemia is used in the treatment of

Correspondence: niazpharmacist@yahoo.com

Department of Pharmacology, Institute of Basic Medical Sciences, Khyber Medical University, Peshawar, KPK, Pakistan asthma, diarrhoea, amenorrhea and other gastro intestinal disorders. Genus asclepiadaceae, in Pakistan, is represented mainly by two species i.e. Tylophora hirsuta and Tylophora tenerrima. Tylophora is of great medicinal importance. It is used, traditionally, for the treatment of asthma, diarrhoea, rheumatism, management of hypertension and other allergic conditions [4]. It is mentioned in Bengal Pharmacopoeia since 1884. Other reported activities are anti-allergic and anti-arthritic [5,6]. Cytotoxic activities of Tylophora asthmatica has been reported in male rats [7]. So far, reported alkaloids from Tylophora hirsuta are 13 a-methylo-hirsutine, tylohersutinine, 13a-methyltylo-hirsutinidine and tylohirsutinidine [8,9]. In 1987, Bhutani et al. reported its anti-amoebic activity [10]. Other reported constituents from the aerial parts of the Tylophora hirsuta are Gymnorhizol, and $\beta$-sitosterol [11]. We have reported that crude methanol extract of Tylophora hirsuta has antispasmodic activity where we emphasized for isolation of pharmacologically active 
compounds. The current work is an attempt for isolation of pharmacologically active compound(s). Brine shrimp cytotoxicity of crude methanol extract is also performed.

\section{Methods \\ Collection, authentication and extraction of plant materials}

The aerial parts of the plant were collected from the nearby hills of University of Malakand in the year 2006. The plant was identified by professor Dr. Jehandar Shah, Vice Chancellor University of Malakand. A voucher specimen (Th.01) was submitted to the herbarium of University of Malakand. The materials were subjected to shade drying. They were crushed and pulverized to fine powder. $7.5 \mathrm{~kg}$ of dried powdered materials were macerated with commercial grade methanol (80\%) for 15 days. The materials were filtered. The filtrates were concentrated under reduced pressure using a rotary evaporator till we obtained 1200 grams of brownish crude extract (free of solvent).

\section{Preliminary phytochemical screenings}

Preliminary phytochemical tests were performed for the presence of alkaloids, flavonoids, tannins, saponins, glycosides, terpenoids, sterols and carbohydrates [12-14].

\section{Solvents and chemicals}

Commercial grade solvents were double distilled, which were used in the experiments. Analytical grade chemicals (Merck) were used in the experiments. All solutions were made on the same day of experiments.

\section{Drugs and animals}

Acetylcholine was purchased from Poole chemicals, UK. Rest of the chemicals were purchased from Merck. Rabbits of either sex (weighing 1.5-2.5 kg) were purchased from the local market. They were housed in the animal house of University of Malakand. They were dealt as per "Animals Byelaws 2008 of the University of Malakand". Ethical Committee of Department of Pharmacy, University of Malakand approved the experimental protocols (case no: E-03-7).

\section{Spectroscopy}

Hitachi U-3200 Spectrophotometer was used for the determination of UV spectra. Infrared (IR) spectra were measured as a potassium bromide $(\mathrm{KBr})$ pellet or in chloroform on JASCO 302-A Infrared Spectrometer. Low-resolution electron impact mass spectra were recorded on a MAT 311A mass spectrophotometer or Finnigan MAT 312 double-focusing mass spectrophotometer, coupled with PDP 11/34 computer system. HREIMS measurements and Fast Atom Bombardment mass measurement were determined on Jeol JMS HX
110 mass spectrometer. ${ }^{1} \mathrm{H}-\mathrm{NMR}$ spectra were recorded at $300 \mathrm{MHz}$ on Bruker AM-300 using TMS as an internal reference.

\section{Isolation of compounds}

Column chromatography $(\mathrm{CC})$ was carried out on silica gel (Si 60, 70-230 mesh, E. Merck) as stationary phase. Organic solvents like $n$-hexane, chloroform, ethyl acetate, $n$-butanol were used as mobile phase(s) as mixture for separation of compounds. For the purification of fractionated extracts, flash column chromatography (FCC) was performed on Eyela Flash Chromatograph model EF-10, using silica gel (Si 60, 230-400 mesh, E. Merck grade) as adsorbent. Pre-coated silica gel $\mathrm{GF}_{254}$ preparative plates (E. Merck) of $20 \times 20$ and $0.5 \mathrm{~mm}$ thickness were used for preparative layer chromatography. Purity of the samples was also checked on the same pre-coated aluminium cards using suitable spray agent.

\section{Spray reagents for visualization of spot(s)/compound(s)} Saturated solution of Ceric Sulphate in 65\% sulphuric acid [15] is used to locate the substances on TLC plates. On heating terpenoids gave pink color.

\section{Fractionation for isolation}

1000 grams of crude methanolic extract was suspended in $500 \mathrm{ml}$ distilled water. It was fractionated with $n$-hexane $(3 \times 450 \mathrm{~mL})$, chloroform $(3 \times 450 \mathrm{~mL})$, ethyl acetate $(3 \times 450 \mathrm{~mL})$ and $n$-butanol $(3 \times 450 \mathrm{~mL})$ to yield $n$ - hexane (500 g), chloroform (45 g), ethyl acetate (20 g), $n$-butanol (5 g) and aqueous (250 g) fractions, respectively. $100 \mathrm{~g}$ of crude methanolic extract was reserved for other pharmacological screenings.

Solvent system was developed using ethyl acetate: $n$-hexane mixture with increasing order of polarity. The $n$-hexane fraction was loaded in a column as it showed antispasmodic activity (data not shown). The contents were eluted with increasing order of polarity: $n$-hexane: ethyl acetate solvent system i.e. $100 \% n$-hexane, $2 \%$ ethyl acetate, $4 \%$ ethyl acetate, $6 \%$ ethyl acetate till $100 \%$ ethyl acetate was passed through the column.

Compound $\mathbf{1}$ was isolated at $3.5 \%$ ethyl acetate: $n$-hexane solvent system in a separate pencil column.

Compound 2 was obtained from $n$-hexane fraction using $n$-hexane: ethyl acetate (11.5:1) as solvent system.

\section{Data recording for effects on spontaneous rabbits' jejunal preparations}

Data was recorded with help of force Transducer (Model No: MLT 0210/A Pan Lab S.I.) connected with Power lab (Model No: 4/25 T) ADInstruments, Australia. Bridge Pod Amplifier connected with the Power lab was used for amplification of the intestinal responses. Other 
setting parameters were in range of $20 \mathrm{mv}$, Low pass $5 \mathrm{~Hz} \times 10$ gain (input 1) and @ 40/S.

\section{Interpretation of data and statistical analysis}

Chart 5, supplied with the Power Lab, was used to interpret the data. Statistical analysis was performed at 95\% confidence interval. $P$ value equal to or less than 0.05 was considered as significant. Graph Pad prism was used to calculate mean, SEM and draw the curves for $\mathrm{EC}_{50}$ shift.

Table $1{ }^{13} \mathrm{C}$-NMR ( $\mathrm{CDCl}_{3} 75 \mathrm{MHz}$ ) chemical shifts and multiplicities of ompound $a$ - amyrin acetate

\begin{tabular}{|c|c|c|}
\hline C. NO & ${ }^{13} \mathrm{C}-\mathrm{NMR}$ & Multiplicity (DEPT) \\
\hline 1 & 38.5 & $\mathrm{CH}_{2}$ \\
\hline 2 & 23.4 & $\mathrm{CH}_{2}$ \\
\hline 3 & 80.9 & $\mathrm{CH}$ \\
\hline 4 & 37.7 & C \\
\hline 5 & 55.3 & $\mathrm{CH}$ \\
\hline 6 & 18.3 & $\mathrm{CH}_{2}$ \\
\hline 7 & 32.9 & $\mathrm{CH}_{2}$ \\
\hline 8 & 39.7 & C \\
\hline 9 & 47.7 & $\mathrm{CH}$ \\
\hline 10 & 36.8 & C \\
\hline 11 & 22.8 & $\mathrm{CH}_{2}$ \\
\hline 12 & 124.2 & $\mathrm{CH}$ \\
\hline 13 & 139.5 & C \\
\hline 14 & 42.1 & C \\
\hline 15 & 28.2 & $\mathrm{CH}_{2}$ \\
\hline 16 & 26.7 & $\mathrm{CH}_{2}$ \\
\hline 17 & 33.8 & C \\
\hline 18 & 59.0 & $\mathrm{CH}$ \\
\hline 19 & 39.7 & $\mathrm{CH}$ \\
\hline 20 & 39.7 & $\mathrm{CH}$ \\
\hline 21 & 31.3 & $\mathrm{CH}_{2}$ \\
\hline 22 & 41.6 & $\mathrm{CH}_{2}$ \\
\hline 23 & 28.1 & $\mathrm{CH}_{3}$ \\
\hline 24 & 15.8 & $\mathrm{CH}_{3}$ \\
\hline 25 & 14.2 & $\mathrm{CH}_{3}$ \\
\hline 26 & 16.8 & $\mathrm{CH}_{3}$ \\
\hline 27 & 17.6 & $\mathrm{CH}_{3}$ \\
\hline 28 & 28.8 & $\mathrm{CH}_{3}$ \\
\hline 29 & 23.3 & $\mathrm{CH}_{3}$ \\
\hline 30 & 21.4 & $\mathrm{CH}_{3}$ \\
\hline COMe & 21.5 & $\mathrm{CH}_{3}$ \\
\hline $\mathrm{CO}$ & 170.8 & C \\
\hline
\end{tabular}

\section{Brine shrimp cytotoxicity}

Brine shrimp eggs were hatched. 10 shrimps, $5 \mathrm{ml}$ sea water and extract at concentrations of 10, 100 and 1000 ppm were added to a vial. After incubation of 24 hours on room temperature, brine shrimp cytotoxicity was performed. Numbers of shrimps survived were counted. Per cent cytotoxicity was determined [16].

\section{Effects on spontaneous rabbits' jejunum preparations and $\mathrm{KCl}$ induced contractions}

Rabbits of either sex (weight $1.9-2.5 \mathrm{~kg}$ ) were subjected to cervical dislocation. Their abdomens were opened. Pieces of jejunums were removed and kept in Tyrode's solution aerated with carbogen gas (95\% oxygen: 5 carbon dioxide mixture). Mesentery was removed from the tissues. Concentration of constituents of used in Tyrode's solution were $(\mathrm{mM}): \mathrm{KCl} 2.68, \mathrm{NaCl} 136.9$, $\mathrm{MgCl}_{2}$ 1.05, $\mathrm{NaHCO}_{3} 11.90, \mathrm{NaH}_{2} \mathrm{PO}_{4} 0.42, \mathrm{CaCl}_{2} 1.8$ and glucose 5.55. Preparations of about $1.3-1.5 \mathrm{~cm}$ lengths were mounted in $10 \mathrm{ml}$ tissue bath containing Tyrode's solution. Temperature was maintained as $37 \pm 1^{\circ} \mathrm{C}$. After stabilization, $\alpha$-amyrin acetate was applied in molar concentrations $2.3 \times 10^{-5}-243 \times 10^{-5}$.

Similarly, sustained contractions were produced by 80 $\mathrm{mM}$ solution of $\mathrm{KCl}$ in the rabbits' jejunum. $\alpha$-amyrin acetate was also tested on rabbits jejunal preparation in same concentrations to explain its mode of action $[17,18]$.

\section{Results}

Upon preliminary phytochemical screenings, methanol extract tested positive for flavonoids, saponins, tannins, glycosides, terpenoids, sterols, phenols and carbohydrates.

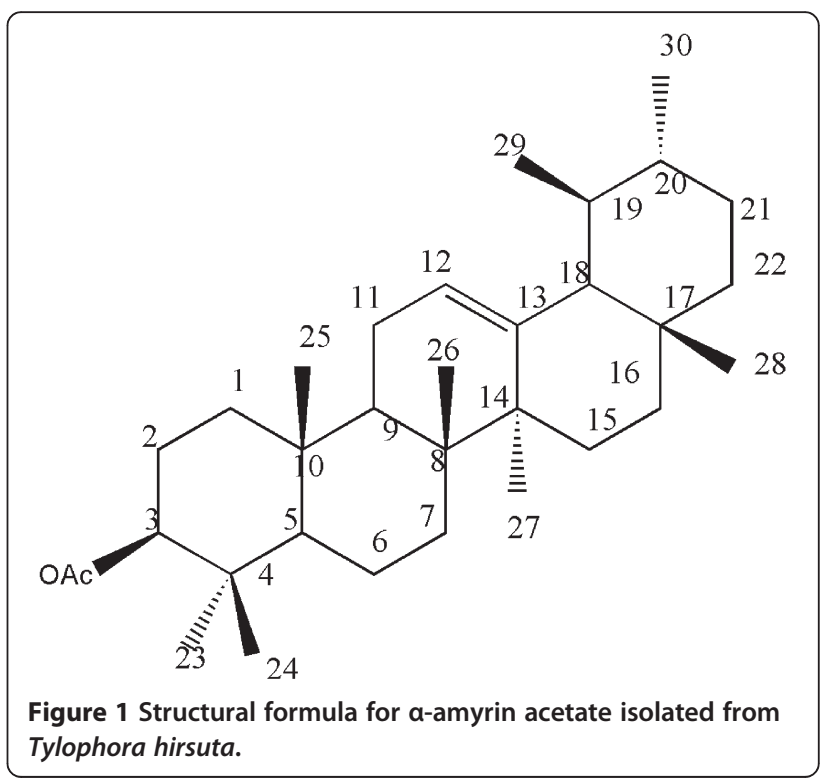




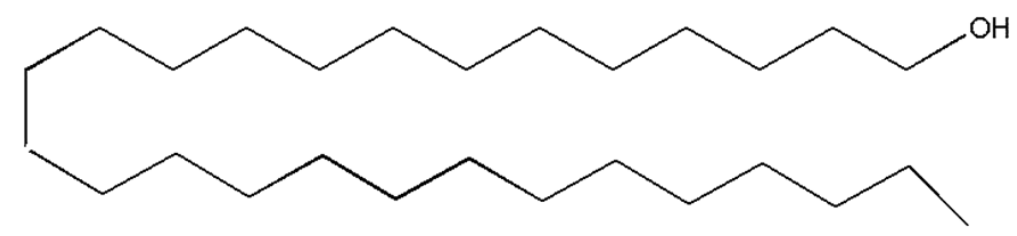

Figure 2 Structural formula for Heptaeicosanol isolated from Tylophora hirsuta.

\section{Spectroscopy results for characterization of $a$ - amyrin} acetate

Physical data: Colourless crystalline needles.

Yield: $6.5 \mathrm{~g}, 1.15 \%$

MP: $243^{\circ} \mathrm{C}$

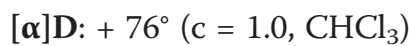

IR (KBr), v $v_{\max }: 1730(\mathrm{C}=\mathrm{O}), 1640(\mathrm{C}=\mathrm{C}), 1380\left(\mathrm{CH}_{3^{-}}\right)$, $1370\left(\mathrm{CH}_{3}-/ \mathrm{CH}_{3} \mathrm{CO}\right), 1250\left(-\mathrm{CH}_{2}-\right), 1030,1000,985$, $960(\mathrm{C}-\mathrm{H}) \mathrm{cm}-1$

${ }^{\mathbf{1}}$ H NMR: $\left(300 \mathrm{MHz}, \mathrm{CDCl}_{3}\right): \delta 0.79(3 \mathrm{H}, s, \mathrm{H}-28)$, 0.88 (12H, s, H-23, 24, 29, 30), 0.98 (3H, s, H-26), 1.01 (3H, s, H-25), 1,07 (3H, s, H-27), 2.05 (3H, s, OAc), 4.50 $(1 \mathrm{H}, d d, J 9.7 \mathrm{~Hz}, \mathrm{H}-3 \alpha), 5.12\left(1 \mathrm{H}, t, J_{1,2} 3.6 \mathrm{~Hz}, J_{1,3}\right.$ $\mathrm{H}-12$ )

EI-MS: (70 ev) $m / z$ (rel. int): $468[\mathrm{M}]^{+}, 453$ (10), $408+$ (20), 218 (100), 203 (10)

${ }^{13} \mathrm{C}-\mathrm{NMR}\left(\mathrm{CDCl}_{3}, 75 \mathrm{MHz}\right)$ : Results of ${ }^{13} \mathrm{C}-\mathrm{NMR}$ is presented in Table 1 that represents the number of carbon atoms with their respective position in molecule. Structure resolved for is $\alpha$ - amyrin acetate expressed in Figure 1.

\section{Spectroscopy results for characterization of Heptaeicosanol (2)}

Physical data: White solid from $n$-hexane fraction MP: $81.6^{\circ} \mathrm{C}$

IR(KBR) $\boldsymbol{v}_{\text {max }}: 3430$ (H-bonded) and $720\left[\left(\mathrm{CH}_{2}\right) \mathrm{n}\right.$ where $\mathrm{n}>4 \mathrm{C} \mathrm{cm}^{-1}$

${ }^{1} \mathbf{H N M R}\left(\mathbf{C D C l}_{\mathbf{3}} 300 \mathrm{MHz}\right): \delta 0.88(3 \mathrm{H}, J=7.1 \mathrm{~Hz})$, $4.28(2 \mathrm{H}, \mathrm{t}, J=6.7 \mathrm{~Hz}, \mathrm{H}-1), 1.28(\mathrm{~m}, \mathrm{CH} 2)_{\mathrm{n}}$.

HREI-MS m/z: 396.4329 (Calcd. For $\mathrm{C}_{27} \mathrm{H}_{26} \mathrm{O}$; 396.4331)

Based on the spectroscopy, the structure resolved for compound 2 is expressed in Figure 2.

Brine shrimps cytotoxicity of crude methanol extract Results of Brine shrimps cytotoxicity studies are summarized in Figure 3. The $\mathrm{LC}_{50}$ is $492.33 \pm 8.08(\mathrm{n}=3) \mathrm{mg} / \mathrm{ml}$ for crude methanol extract.

Effects on spontaneous rabbits' jejunal preparations and $\mathrm{KCl}(80 \mathrm{mM})$-induced contractions

The relaxing effects of $\alpha$-amyrin acetate on spontaneous rabbits' jejunal preparations and $\mathrm{KCl}$-induced contractions are expressed in Figure 4. Compound 1 produced relaxing effect as its concentration in the bath increased. Corresponding $\mathrm{EC}_{50}$ values for spontaneous and $\mathrm{KCl}$ - induced contractions are $(60 \pm 2) \times 10^{-5} \mathrm{M}$ and $(72 \pm 3) \times 10^{-5} \mathrm{M}$.

\section{Discussion}

The compound $\mathbf{1}$ was isolated as colourless needles from $n$-hexane fraction of methanolic extract of the aerial parts of Tylophora hirsuta.

The EI-MS of compound $\mathbf{1}$ showed the molecular ion peak at $m / z 468$, which was in agreement with the molecular formula $\mathrm{C}_{32} \mathrm{H}_{52} \mathrm{O}_{2}$ (calcd. $m / z$ 468.) consistent with seven degrees of unsaturation. Besides molecular ion in the EI-MS, the mass spectrum showed characteristic fragmentation pattern of amyrin type skeleton with the double-bond at C-12 [19]. The IR spectrum displayed absorptions at 1730 and $1640 \mathrm{~cm}^{-1}$ due to the carbonyl and olefinic functions, respectively.

The study of ${ }^{1} \mathrm{H}$-NMR spectrum $\left(\mathrm{CDCl}_{3}, 300 \mathrm{MHz}\right)$ of compound 1 showed signals for methyls, methylenes and methin protons. In the up field region of the spectrum singlets each of three protons integration resonating at $\delta 0.97,0.77,0.94,1.01,1.13,0.83$ and 0.87 $(6 \mathrm{H})$ were assigned to tertiary methyls. In the downfield region of the spectrum a triplet of one proton integration resonating at $\delta 5.18$ having a coupling constant $\mathrm{J}=4.0 \mathrm{~Hz}, \delta 2.05$ was assigned to the olefinic protons $\mathrm{H}-12$. Similarly a double doublet of one proton integration at $\alpha 3.21$, with a coupling constant 10.2 and $4.3 \mathrm{~Hz}$ was

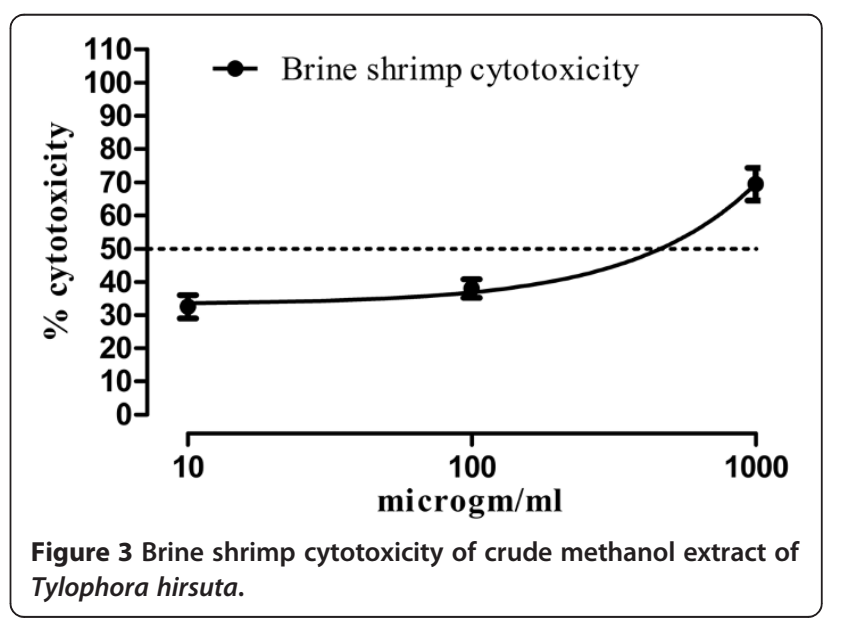




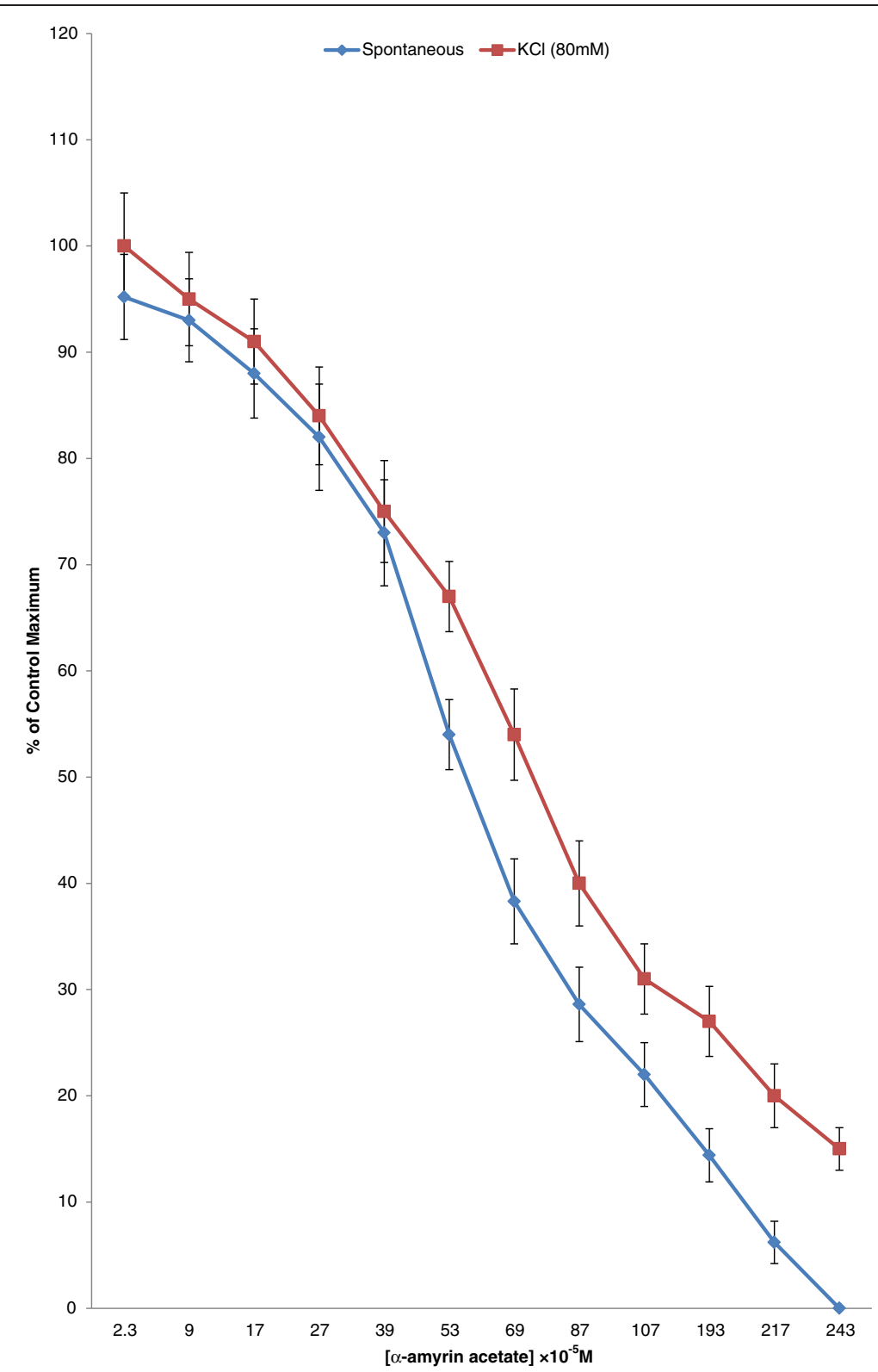

Figure 4 The effects of $a$-amyrin acetate on spontaneous and $\mathrm{KCl}$-induced contractions (values are mean $\pm \mathrm{SEM}, \mathrm{n}=4, P<0.05$ ).

assigned to $\mathrm{H}-3$ a proton gemminal to acetate group. While a singlet of three proton integration resonating at $\delta$ 2.05 was assigned to methyl of acetate group attached at $\mathrm{C}-3$.

The ${ }^{13} \mathrm{C}$-NMR spectrum (Broad band, DEPT) of compound 1 (Table 1) showed thirty two signals including nine methyls, nine methylenes, six methines and six quaternary carbons. The ${ }^{1} \mathrm{H}-{ }^{13} \mathrm{C}$ correlations were determined by HMQC spectrum. In the ${ }^{13} \mathrm{C}$-NMR spectrum of compound-1, the up field resonance at $\delta 28.1,15.8,14.2$, $16.8,17.6,28.8,23.3$ and 21.4 were due to the tertiary methyls while the signal at $\delta 21.5$ was assigned to the carbon of methyl of acetate group. Similarly, in the down field region, the resonance at $\delta 170.8$ and 124.2 were assigned to the carbonyl carbon and olefinic C-12. While the signal at $\delta 139.1$ was due to the quaternary $\mathrm{C}-13$ carbon.

The chemical shifts of these signals and other physical data were found identical to $\alpha$-amyrin acetate (Figure 1) [20-23]. Compound 2 was obtained from the $n$-hexane fraction of the methanolic extract of aerial parts of Tylophora hirsuta. The structure of compound $\mathbf{2}$ was established by IR, mass and NMR spectroscopy. The molecular formula $\mathrm{C}_{25} \mathrm{H}_{52} \mathrm{O}$ was based on the HREIMS, FD and ${ }^{13} \mathrm{C}$-NMR spectra. HR-EIMS showed a molecular ion peak at $\mathrm{m} / \mathrm{z} 368.01$ (calcd. for $\mathrm{C}_{25} \mathrm{H}_{52} \mathrm{O}$ 368.04), 
suggesting the molecular formula $\mathrm{C}_{25} \mathrm{H}_{52} \mathrm{O}$. The ${ }^{1} \mathrm{H}-\mathrm{NMR}$ spectrum displayed a triplet at $\delta 0.86(J=7.0 \mathrm{~Hz})$ and a broad singlet at $\delta 1.21$ typical of a straight chain hydrocarbon. It also showed signals at $\delta 3.85(\alpha \mathrm{H}, \mathrm{H}-1)$ respectively. The ${ }^{13} \mathrm{C}-\mathrm{NMR}$ spectrum (BB and DEPT) was also very informative in the structure elucidation of compound 2 . One oxygenated methylene resonated at $\delta 63.21$ respectively. The signals observed between 29.0- 29.73 indicated the presence of a long chain hydrocarbon and the data correlated with reported literature [24]. The position of the hydroxyl group was also confirmed by the HMBC experiments (data not shown). Thus the structure of compound 2 was resolved as Heptaeicosanol (Figure 2).

The results of brine shrimps cytotoxicity study, $\mathrm{LC}_{50}$ is $492.33 \pm 8.08(\mathrm{n}=3) \mathrm{mg} / \mathrm{ml}$, reveal that the plant species can also be a potential source of cytotoxic compound(s).

As the plant is rich source of terpenes and terpenoids, hence our findings are in consistent with phytochemistry as $\alpha$-amyrin acetate was the major compound isolated for the first time from Tylophora hirsuta. Being a major compound, the molecule was tested for possible relaxant activity on spontaneous rabbits' jejunal preparations. It relaxed the spontaneous contractions and showed a concentration dependent relaxing effects. Since there are many mechanisms involved in the relaxing effects like relaxing effects either may be through calcium antagonistic action or through muscarinic receptors blocking mechanisms. There may be involvement of histaminergic receptors. Nevertheless, relaxing effects on $\mathrm{KCl}$-induced contractions provides a rapid screening for possible relaxing mechanisms through voltage gated channels [25]. Voltage gated channels play a vital role in the regulation of peristaltic movements of the intestine as it helps in periodic depolarization and repolarization [26]. Since $\mathrm{KCl}$ induces contractions via calcium influx from extracellular fluid to intracellular medium, hence, relaxing effects on $\mathrm{KCl}$-induced contractions are usually regarded as to follow calcium channel blocking mechanism [18]. Further work is required to elucidate possible mechanism by constructing calcium chloride curves and study its effects for possible relaxing mechanism. $\alpha$-amyrin acetate can be a potential target for new drug development for management of hypertension and other cardiovascular disorders as calcium antagonists have antianginal, antihypertensive, and antiarrhythmic activity. The current work is further strengthening our previous reports about crude methanol extract of Tylophora hirsuta to have antihypertensive [27] and calcium channel blocking activity [4].

\section{Conclusions}

$\alpha$-amyrin acetate and Heptaeicosanol is reported for the first time from Tylophora hirsuta. The relaxing effect of Tylophora hirsuta may be attributed to $\alpha$-amyrin acetate a major compound from the plant that warrants further work for new drug development.

\section{Competing interests}

The author has declared no competing interests.

\section{Acknowledgements}

The author thanks Professor Dr. Jehandar Shah for identifying the plant. The author also wants to thank Dr. Javed Hussain, Assistant Professor,

Department of Chemistry, Kohat University of Science and Technology, Kohat, for helping in resolving the spectra of the compounds.

Received: 24 December 2012 Accepted: 13 June 2013

Published: 17 June 2013

\section{References}

1. Ali SI: Asclepiadaceae. In Flora of Pakistan vol. 150. Edited by E Nasir, Ali SI. Karachi: Shamim Printing Press; 1983:42-43.

2. Srivpuri DN, Singhal SC, Parkash D: Treatment of asthma with an alcoholic extract of Tylophora indica- a cross-over, double-blind study. Ann Allergy 1972, 30(Suppl 7):407-412.

3. Kumar S, Nagyan P: Assessment and Conservation of Medicinal Plant Wealth of Haryana. In Medicinal Plants; Ethnobotanical approach. Edited by Trividi PC. Jodhpur: Agrobios; 2006:176-177. 271.

4. Ahmad B, Ali N, Bashir S, Azam A, Ibrar M, Khan J: Cholinomimetic and calcium channel blocking activity of the aerial parts of Tylophora hirsuta wall. J Chem Soc Pak 2009, 31:647-651.

5. Gopalakrishnan C, Shankaranarayanan D, Nazimudeen SK: Effect of tylophorine, a major alkaloid of Tylophora indica, on immuno-pathological and inflammatory reactions. Indian J Med Res 1980, 71:940-948.

6. Wagner $\mathrm{H}$ : Search for new plant constituents with potential antiphlogistic and antiallergic activity. Planta Med 1989, 55:235-241.

7. Dikshith TS, Raizada RB, Mulchandani NB: Toxicity of pure alkaloid of Tylophora asthmatica in male rat. Indian J Exp Biol 1990, 28:208-212.

8. Bhutani KK, Ali M, Atal CK: Alkaloids from Tylophora hirsuta. Phytochem 1984, 23:1765-1769.

9. Bhutani KK, Ali M, Atal CK: 13a-hydroxytylophorine from Tylophora hirsuta. Phytochem 1985, 24:2778-2780.

10. Bhutani KK, Sharma GL, Ali M: Plant based anti-amoebic drugs. Planta Med 1987, 53:532-536.

11. Ali M, Bhutani KK: Alihirsutine A, a new phenanthroquinolidine alkaloids from Tylophora hirsuta. Fitoterapia 1991, LXIII:243-244.

12. Aduragbenro DA, Yeside OO, Adeolu AA, Olanrewaju MJ, Ayotunde SA, Olumayokun AO, Janet MM: Blood pressure lowering effect of Adenanthera pavonina seed extract on normotensive rats. Rec Nat Prod 2009, 2009(3):282-289.

13. Harborne JB: Phytochemical methods. London: Chapman and Hall; 1973:117.

14. Kokate CK, Purohit AP, Gokhale SB: Practical Pharmacognosy 2nd ed. Pune, Mumbai: Nirali Prakashan; 1994

15. Stahl E: Edition (1969). Thin Layer Chromatography $2^{\text {nd }}$ ed. New York: Springer-Verlag; 1969:861-904.

16. Rehman AU, Choudhary MI, Thomsen: Manual of Bioassay Techniques for Natural Product Research. Amsterdam: Harward Academic Press; 1991:82-84.

17. Ghayur MN, Gilani AH: Pharmacological basis for the medicinal use of ginger in gastrointestinal disorders. Dig Dis Sci 2005, 50:1889-1897.

18. Shah SWA, Kamil SA, Ahmad W, Ali N: Spasmogenic, spasmolytic and antihypertensive activity of Forsskalea tenacissima. Afr J Pharma Pharmacol 2010, 4:381-385.

19. Juang JK, Huang HW, Chen CM, Liu HJ: A new compound, withangulatin A, promotes type II DNA topoisomerase-mediated DNA damage. Biochem Biophys Res Commun 1989, 159(Suppl 3):1128-1134.

20. Matsunaga S, Tanaka R, Akagi M: Tri terpenoids from Euphorbia maculata. Phytochem 1988, 27:535-537.

21. Chen ZS, Lee GH, Kuo YH: Disformone and dischidiol from Dischidia formosana. Phytochem 1993, 34(Suppl 3):783-786.

22. Hisham A, Kumar GJ, Fujimoto Y, Hara N: Salacianone and salacianol, two triterpenes from Salacia beddomei. Phytochem 1995, 40(Suppl 4):1227-1231.

23. Rehana A, Ifazal SM, Usman G: Studies on Achras sapotal: part iv chemistry and pharmacognosy of wood. Pak J Pharmac Sci 2001, 14(Suppl 1):39-40. 
24. Modak B, Torres R, Wilkens M, Urzúa A: Antibacterial activity of compounds isolated of the resinous exudate from Heliotropium sinuatum on phytopathogenic bacteria. J Chil Chem Soc 2004, 49(Suppl 1):1-3.

25. Bolton TB: Mechanism of action of transmitters and other substances on smooth muscles. Physiol Rev 1979, 59:606-718.

26. Karaki H, Wiess G: Mini-review: calcium release in smooth muscles. Life Sci 1983, 42:111-112.

27. Ahmad B, Ali N, Azam S, Bashir S: Blood pressure lowering effect of Tylophora hirsuta Wall. Afr J Biotechnol 2012, 11(Suppl 12):3009-3013.

doi:10.1186/1472-6882-13-135

Cite this article as: Ali: Brine shrimp cytotoxicity of crude methanol extract and antispasmodic activity of a-amyrin acetate from Tylophora hirsuta Wall. BMC Complementary and Alternative Medicine 2013 13:135.

\section{Submit your next manuscript to BioMed Central and take full advantage of:}

- Convenient online submission

- Thorough peer review

- No space constraints or color figure charges

- Immediate publication on acceptance

- Inclusion in PubMed, CAS, Scopus and Google Scholar

- Research which is freely available for redistribution 